\title{
Partial characterization of protease activity in squid (Todaropsis eblanae) mantle: modification by high- pressure treatment
}

Hernández-Andrés, A.; Gómez-Guillén C.; Montero P. and Pérez-Mateos M.*

\author{
Instituto del Frío (CSIC), José Antonio Nováis, 10 - 28040 Madrid, Spain
}

(*) Corresponding author: miriam@if.csic.es (Fax: 34 - 9154936 27) 


\section{ABSTRACT}

Optimum conditions for proteolytic activity in both, non-pressurized and pressurized (300 MPa, $7^{\circ} \mathrm{C}, 20$ min) squid (Todaropsis eblanae) muscle, occurred at acid $\mathrm{pH}$ levels $(\mathrm{pH} 3)$ over a broad range of temperatures. Pressure treatment did not modify optimum $\mathrm{pH}$ and temperatures but did increase proteolytic activity. The acid cysteine proteases and to a lesser extent the acid serine proteases were the enzymes mainly affected by the high-pressure treatment. The SDS-PAGE was indicative of increased protein hydrolysis by pressurization. Myosin heavy chain in both, non-pressurized and pressurized squid, was degraded at all the temperatures tested, but actin was only susceptible to proteolysis in the pressure-treated muscle at $7{ }^{\circ} \mathrm{C}$ and $40{ }^{\circ} \mathrm{C}$. This behavior was not observed at $55^{\circ} \mathrm{C}$.

Key words: Squid, high pressure, proteolysis, protease inhibitors 


\section{Introduction}

Cephalopods make up a significant fraction of living organisms that are fit for human consumption. They are normally consumed in the form of rings or whole when small. Nevertheless, in some cases they are not appropriate for consumption directly because on account of not having an adequate texture, or size. In those cases they can be processed for use in various ways, one process being the manufacture of gels from their muscle. Because cephalopods have a low thermal gelling capacity due to their high levels of proteolytic activity, high-pressure gelling of the muscle protein could be considered as a possible alternative to conventional heat treatment (Montero and others 1997; Fernández-Martín and others 1998).

High-pressure treatments initially originated in food processing to prolong the shelf-life of foodstuffs during storage and retailing, mainly as a means of inactivating microorganisms and denaturing enzymes. High pressure may affect enzymatic reactions directly by altering the kinetic constants or by producing conformational changes in the structure of the enzymes and/or substrates (Morild 1981; Dufour and others 1996). Such pressurization conditions as the amount of pressure, time, temperature, $\mathrm{pH}$, etc. also play a role, and a given reaction may be activated or inhibited depending on the conditions (Defaye and Ledward 1995). Additionally, studies have shown the enzymatic activity pattern to differ depending on

44 whether raw extract or whole muscle is used (Chung and others 1994). Earlier studies have contemplated using high pressure for enzyme denaturation, e.g., inactivation of aminopeptidases and carboxypeptidases at $500 \mathrm{MPa}$ and at $400 \mathrm{MPa}$, respectively (Ohmori and others 1991); of the proteases in spear squid (Loligo bleekeri) mantle at pressures greater than 800 MP (Nagashima and others 1993); of collagenase and cathepsin B at a pressure of $300 \mathrm{MPa}$ (Dufour and others 1996); and activation of the proteolytic reactions in meat at pressures of between 100-300 MPa (Kim and others 1992; Homma and others 1994).

In addition to interfering with gelling (Nagashima and others 1992; Gómez-Guillén and others 1996),

52 the action of the proteolytic enzymes in cephalopod muscle has been observed to lead to rapid 
deterioration, resulting in a loss of quality (Sakai and Matsumoto 1981; Leblanc and Gill 1982; Konno and Fukazawa 1993; Ayensa and others 1999). Most studies on the role of proteases in the breakdown of seafood have dealt with post-mortem deterioration at chilled or high $\left(50-70{ }^{\circ} \mathrm{C}\right)$ temperatures (Wasson 56 1992). Autolysis in frozen mantle and suitability for gelling has also been examined (Gómez-Guillén and others 2003).

Studies carried out using specific and semi-specific enzyme inhibitors have made it possible to characterize the proteases and classify them according to the configuration of their active site. Serine

60 and cysteine proteases have proved to be the most closely involved in gel degradation. Marked reductions in the levels of the rheological properties of the mantle tissue in different cephalopod species has been described and associated with a peak in proteolytic activity related to serine protease activity at a temperature of around $40{ }^{\circ} \mathrm{C}$ (Ebina and others 1995; Gómez-Guillén and others 2002). Cathepsins are

64 the most active cysteine proteases in the muscle, particularly cathepsins $\mathrm{B}$ and $\mathrm{L}$, which interfere significantly with gelling because they are active at high temperatures. Ayensa and others (1999) reported activity by cathepsins $\mathrm{B}$ and $\mathrm{L}$ in the mantle in the squid Todaropsis eblanae.

Enzymatic activity is dependent on muscle $\mathrm{pH}$. Proteolytic activity has been described in the mantle of 68 various cephalopods at acid (Sakai and Matsumoto 1981; Hurtado and others 2002), basic and neutral (Rodger and others 1984; Ayensa and others 1999) pH levels. Similarly, different optimal temperatures have been suggested for different cephalopod species (Rodger and others 1984; Konno and Fukazawa 1993; Hurtado and others 2002).

72 The object of this experiment was to study changes by high pressure treatment in proteolytic activity in squid muscle (Todaropsis eblanae) at different $\mathrm{pH}$ and temperatures. 


\section{Sample preparation and treatment}

84 Squid (Todaropsis eblanae) was obtained from a local market within 24-48 hours of captured and transported in ice to the Instituto del Frío (CSIC), Madrid, Spain. The average weight and length were $113.55 \mathrm{~g}( \pm 37.17)$ and $14.82 \mathrm{~cm}( \pm 1.38)$. The squids were immediately gutted and washed upon arrival. Tentacles were removed and mantles were vacuum-packed in flexible bags (Cryovac BB4L, Barcelona,

88 Spain). Half of the vacuum-packed mantles were subjected to pressure treatment at $300 \mathrm{MPa}$ at $7^{\circ} \mathrm{C}$ for 20 minutes (pressurized batch: P), while the other half were kept at $7{ }^{\circ} \mathrm{C}$ at atmospheric pressure (nonpressurized batch: NP). Conditions for the pressurization were chosen according to the results of previous assays (Pérez-Mateos and Montero 1997; Hurtado and others 2001). High-pressure treatments

92 were performed in a high-pressure pilot unit (ACB 665, Gec Alsthom, Nantes, France) where the temperature of the immersion medium (distilled water) was controlled via a thermo-couple with a programmed thermostatization equipment (model IA/2230 AC, INMASA, Barcelona, Spain). Pressure was increased at $2.5 \mathrm{MPa}$ /s. Both batches were then frozen at $-30{ }^{\circ} \mathrm{C}$ for two hours in an air-blast tunnel

96 freezer (AGA-Frigoscandia 0-6373, Helsingborg, Sweden). Frozen squids were skinned, cut into small pieces and mixed. Samples were vacuum-packed and stored at $-54{ }^{\circ} \mathrm{C}$ to prevent any alterations during storage until analysis.

\section{$100 \quad$ Proximate analysis}

The moisture and ashes content were determined by the method of A.O.A.C. (2000). The crude protein was measured by the method of Dumas following A.O.A.C. 992.15 (A.O.A.C. 2000), with the 104 analyzer LECO (FP-2000 LECO Corporation, St. Joseph, USA). The crude fat determination was realized according to the method of Bligh and Dyer (1959) and later modified by Knudsen and others 
(1985). Results were average of at least three determinations. The majority components of the raw squid mantle were $14.43 \%( \pm 0.13)$ of crude protein; $1.08 \%( \pm 0.03)$ of crude fat; $83.52 \%( \pm 0.22)$ of 108 moisture and $1.14 \%( \pm 0.05)$ of ashes.

\section{Determination of $\mathbf{p H}$}

112 The $\mathrm{pH}$ was determined according to the technique used by Vyncke (1981) in a pHmeter (MeterLab pHM 93, Radiometer Analytical, Copenhagen, Denmark). The result was average of at least three determinations.

\section{Effect of temperature, $\mathbf{p H}$ and $\mathrm{NaCl}$ on proteolytic activity}

To study the effect of temperature on proteolytic activity, the chopped muscle was homogenized in cold $0.2 \mathrm{M}$ phosphate buffer $(\mathrm{pH} 6.5)$ at a ratio of 1:2 (w/v), at 10,000 rpm for $1 \mathrm{~min}$ in an iced water bath, using an Omnimixer (Model ES-231, Homogenizer, Omni International, Waterbury, USA). The homogenates were filtered through 4 layers of cheesecloth in order to remove connective tissue. The range of temperatures assayed were from 20 to $80{ }^{\circ} \mathrm{C}$.

In the $\mathrm{pH}$ profile for proteolytic activity, the buffers used for the homogenization were Mcllvaine

124 buffer (0.2 M sodium phosfate and $0.1 \mathrm{M}$ sodium citrate), for $\mathrm{pH} 2$ to 7 ; and Tris-HCl buffer (0.2 M) for pH 8 and 8.5, all of them at $4{ }^{\circ} \mathrm{C}$. The incubation temperatures were 40 and $55^{\circ} \mathrm{C}$.

In the study of $\mathrm{NaCl}$ effect on proteolytic activity, a cold solution of $\mathrm{NaCl} 0.15 \mathrm{M}$ was used for the homogenization. The incubation temperatures were 40 and $60^{\circ} \mathrm{C}$. $\mathrm{NaCl}$ was supplied by PANREAC 128 (Montplet \& Esteban, S.A., Barcelona, Spain).

Proteolytic activity was assayed according to the modified method of Hurtado and others (1999), using at least three replicates, as follows. Three-gram aliquots of the homogenate, immediately after the preparation of crude homogenate, were incubated for one hour at the different experimental 
temperatures. Following the incubation, adding $6 \mathrm{~mL}$ of cold $10 \%$ trichloroacetic acid (TCA) the proteolysis was stopped. The mixture was kept at $4{ }^{\circ} \mathrm{C}$ for 15 min to allow unhidrolyzed proteins to precipitate, and then they were centrifuged at $6,100 \mathrm{x}$ g for 15 min at $4{ }^{\circ} \mathrm{C}$ (Beckman J2-MC, JA-20 rotor, Calif., USA). The content of soluble oligopeptides in the supernatant was analyzed by the method of Lowry and others (1951) using tyrosine as standard. Absorbance was measured in an UV-visible Spectrophotometer (UV-1601 SHIMADZU, Tokyo, Japan). Activity was expressed as $\mu$ moles of tyrosine released per gram of muscle per hour of incubation ( $\mu \mathrm{mol} \mathrm{Tyr} / \mathrm{g} / \mathrm{h})$. The results were average of at least 3 determinations. In all cases the blank was the result got for a three-gram aliquot that was introduced in an iced bath at $0{ }^{\circ} \mathrm{C}$ for incubation time.

\section{Sample preparation for electrophoresis}

144 The squid mantle muscle (NP and P batches) was finely cut manually. The chopped muscle, $1 \mathrm{~g}$, was incubated in a water bath at 40 or $55^{\circ} \mathrm{C}$ for various periods: 0,4 and 8 hours. Also $1 \mathrm{~g}$ of the chopped muscle was held for 0,8 and 24 hours at chilling temperature $\left(7^{\circ} \mathrm{C}\right)$. After the incubation, $9 \mathrm{~mL}$ of 20 mM of solubilization buffer (20 mM Tris-HCl, pH 8.0, containing 2 \% $\beta$-mercaptoethanol (Merck), 2 \%

SDS (Bio-Rad), and $8 \mathrm{M}$ urea) was added and followed by continuous shaking for $16-24 \mathrm{~h}$ at room temperature. Insoluble material in homogenates was centrifuged at 10,000 x g (MR 18.12 Centrifuges, JOVAN, Saint Herblain, France) for $20 \mathrm{~min}$ at room temperature. The supernatant was analyzed for protein concentration by the method of Bradford (1976), as well as for myofibrillar protein degradation

152 on sodium dodecyl sulfate gel electrophoresis (SDS-PAGE). For electrophoresis analysis, an aliquot of the supernatant was taken and added to $200 \mu \mathrm{L}$ of the denaturing SDS-PAGE sample treatment buffer: 5 \% $\beta$-mercaptoethanol, $2.5 \%$ SDS, 10 mM Tris-HCl, 1 mM ethylenediaminetetra-acetic acid (EDTA) (Sigma Chemical Co). and $0.002 \%$ bromophenol blue (PANREAC), and finally was got a final 156 concentration of $2 \mathrm{mg} / \mathrm{mL}$ by adding distilled water. This mixture was boiled for $5 \mathrm{~min}$ at $100{ }^{\circ} \mathrm{C}$. 


\section{SDS-PAGE}

160 Electrophoresis was carried out by the method of Laemmli (1970) using $10 \%$ polyacrylamide gels. The proteins were separated at a constant current of $30 \mathrm{~mA}$. Separated protein bands were stained with brilliant Coomassie blue (R-250, Merck). The gel was de-stained in an aqueous solution of $30 \%$ methanol and $10 \%$ acetic acid. A high-molecular-weight standard (HMW, Pharmacia-Biotech) and

164 another low-molecular-weight standard (LMW, Amersham Biosciences) were used to calculate the molecular weights of the proteins. The HMW consisted of myosin (220 KDa), $\alpha_{2}$-macroglobulin (170 KDa), $\beta$-galactosidase (116 KDa), transferrin (76 KDa), and glutamic dehydrogenase (53 KDa). The LMW consisted of phophorilase b (97 KDa), albumin (66 KDa), ovoalbumin (45 KDa), carbonic anhydrase (30 KDa), trypsin inhibitor (20.1 KDa) and $\alpha$-lactoalbumin (14.4 KDa).

\section{Inhibition of proteolytic activity}

172 Crude enzyme extract was prepared from chopped mantle muscle of both pressurized and nonpressurized squid. Chopped muscle was mixed with a $20 \mathrm{mM}$ phosphate buffer, pH 6.5 at a 1:2 (w/v) ratio and homogenized in iced water for $1 \mathrm{~min}$ at 10,000 rpm. The homogenate was centrifuged (Beckman J2-MC, JA-14 rotor, Calif., CA, USA) at 20,000 x g for $40 \mathrm{~min}$ at $4{ }^{\circ} \mathrm{C}$, and the supernatant was used as a source of enzyme.

The following inhibitors were tested to classify proteinases in squid mantle muscle: $1 \mathrm{mM}$ iodoacetic acid (IA) as a cysteine protease inhibitor; $1 \mathrm{mg} / \mathrm{mL}$ phenylmethyl sulphonyl fluoride (PMSF) as a serine protease inhibitor; $0.2 \mu \mathrm{g} / \mathrm{mL}$ pepstatine A (Peps. A) as an aspartic protease inhibitor; and $10 \mathrm{mM}$ ethylenediaminetetra-acetic acid (EDTA) as a metallo-protease inhibitor. All the inhibitors tested were from Sigma Chemical Co. $20 \mathrm{mM} \mathrm{NaCl}$ was also assayed to study it as a possible activator of proteolysis. The concentrations were chosen based on previously reported proteinase classification 
studies (Hameed and Hard 1985; An and others 1994; Seymour and others 1994; Ayensa and others 1999; Hurtado and others 1999). In all cases, $100 \mu \mathrm{L}$ of the stock solution of inhibitor was added to the enzymatic extract ( $400 \mu \mathrm{L})$ to give the final inhibitor concentrations. The enzyme-inhibitor mixtures were preincubated for $15 \mathrm{~min}$ at room temperature prior to assay for residual proteolytic activity as follows.

The preincubated enzyme-inhibitor mixture was mixed with $400 \mu \mathrm{L}$ of Mc Ilvaine buffer of different $\mathrm{pH}$ depending on the conditions. The mixtures were then incubated in a thermostatic water bath for $1 \mathrm{~h}$ at the temperature chosen. The conditions for the assay were $\mathrm{pH} \mathrm{3,40}{ }^{\circ} \mathrm{C}$ and $55{ }^{\circ} \mathrm{C}$; $\mathrm{pH} 6.5,40{ }^{\circ} \mathrm{C}$; and $\mathrm{pH} 8.0,40{ }^{\circ} \mathrm{C}$.

192 After the incubation $100 \mu \mathrm{L}$ of $50 \%(w / v)$ TCA was added to stop the reaction. The mixture was incubated for $15 \mathrm{~min}$ at $4{ }^{\circ} \mathrm{C}$ to allow unhydrolyzed proteins to precipitate, followed by centrifugation at 5,700 x g for 10 min (MicroSpin 24S, Sorvall Instruments, DuPont, Wilmington, DEL., USA). TCAsoluble peptides in the supernatant were analysed by the method of Lowry and others (1951). Residual 196 proteolytic activity was expressed as $\mu$ moles of tyrosine released per gram of sample per hour of incubation ( $\mu \mathrm{mol} \mathrm{Tyr} / \mathrm{g} / \mathrm{h})$.

In all cases a blank and control were included. The result for the blank (without inhibitor and no incubated) corresponds to existing peptides in $1 \mathrm{~g}$ of muscle no incubated. The control, without inhibitor 200 and incubated at the corresponding temperature, assumes $100 \%$ of proteolytic activity.

\section{Statistical analysis}

204 Data were subjected to analysis of variance using SPSS computer program (SPSS 11.5, SPSS INC., Chicago, Illinois, USA), paired comparisons were made using Bonferroni test or Tamhane test, with significance of difference set at $\mathrm{p} \leq 0.05$, depending on variance homogeneity. Differences of means due to treatment were using a $\mathrm{T}$ test. 


\section{Results and Discussion}

\section{Determination of muscle $\mathrm{pH}$}

The $\mathrm{pH}$ of non-pressurized and pressurized squid muscle was $6.47( \pm 0.01)$ and $6.69( \pm 0.03)$,

216 respectively. Squid muscle $\mathrm{pH}$ rose slightly upon pressurization, a finding probably related to denaturation of certain protein fractions. Angsupanich and Ledward (1998) reported similar behavior in high pressure-treated cod (Gadus morhua) muscle.

\section{The effect of temperature on proteolytic activity}

Figure 1 depicts the proteolytic activity in a range of temperatures between 20 and $80{ }^{\circ} \mathrm{C}$. Proteolysis was observed over the entire range of temperatures studied, with proteolytic activity increasing 224 appreciably between 35 and $65^{\circ} \mathrm{C}$. This is consistent with the high level of enzymatic activity in cephalopod muscle because of the high rate of protein turnover that goes hand in hand with high growth rates (Sakai and Matsumoto 1981; Leblanc and Gill 1982; Konno and Fukazawa 1993). 


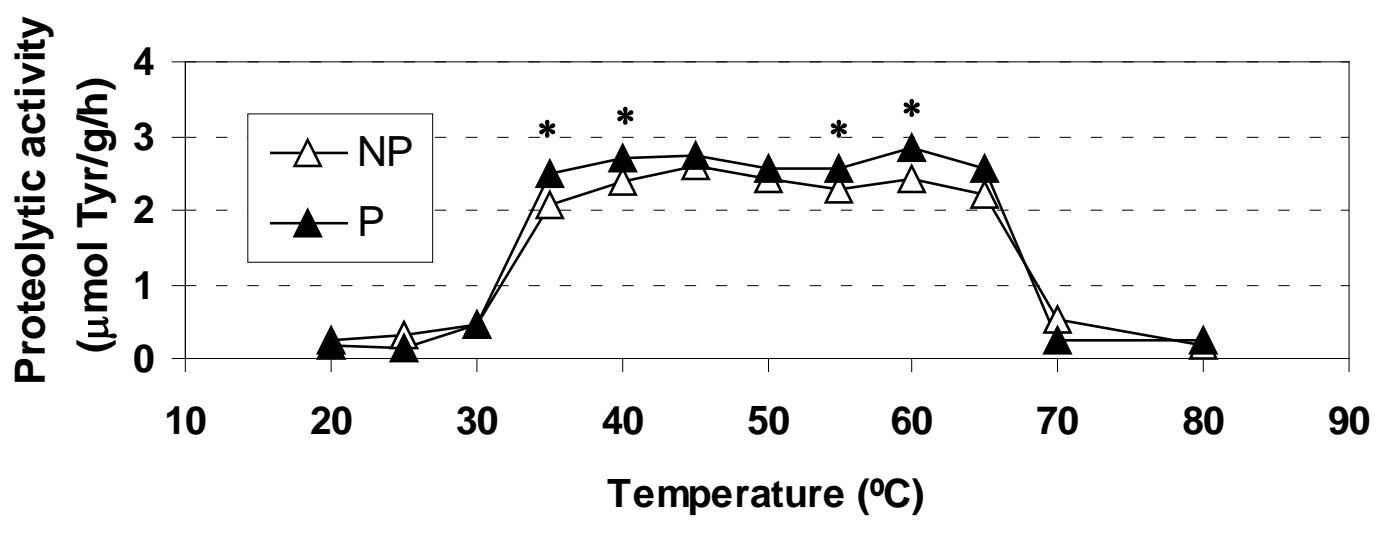

\begin{tabular}{cccccccccc}
\hline & \multicolumn{10}{c}{ Temperature $\left({ }^{\circ} \mathrm{C}\right)$} \\
Batch & $\mathbf{2 0 - 3 0}$ & $\mathbf{3 5}$ & $\mathbf{4 0}$ & $\mathbf{4 5}$ & $\mathbf{5 0}$ & $\mathbf{5 5}$ & $\mathbf{6 0}$ & $\mathbf{6 5}$ & $\mathbf{7 0 - 8 0}$ \\
NP & $\mathrm{a}$ & $\mathrm{b}$ & $\mathrm{bc}$ & $\mathrm{c}$ & $\mathrm{bc}$ & $\mathrm{bc}$ & $\mathrm{bc}$ & $\mathrm{bc}$ & $\mathrm{a}$ \\
P & $\mathrm{a}$ & $\mathrm{b}$ & $\mathrm{b}$ & $\mathrm{b}$ & $\mathrm{b}$ & $\mathrm{b}$ & $\mathrm{b}$ & $\mathrm{b}$ & $\mathrm{a}$ \\
\hline
\end{tabular}

Figure 1. Proteolytic activity profile in non-pressurized (NP) and pressurized (P) squid mantle at different temperatures. Different letters (a, b, c) indicate significant differences $(\mathrm{p} \leq 0.05)$ for the same batch at different temperatures. $(*)$ indicates significant differences $(\mathrm{p} \leq 0.05)$ between the batches at each temperature.

Pressurization did not cause any variation in the proteolytic activity pattern of temperature, though enzymatic activity did increase significantly at $35-40{ }^{\circ} \mathrm{C}$ and $55-60{ }^{\circ} \mathrm{C}$. The high level of activity at high temperatures indicates the presence of heat-stable, pressure-resistant proteases in the muscle. Various 236 researchers have reported peak proteolytic activity levels in different cephalopod species at temperatures of around $40^{\circ} \mathrm{C}$. According to Konno and Fukazawa (1993) proteolysis in the muscle of the squid Todarodes pacificus increased with temperature up to $40{ }^{\circ} \mathrm{C}$ and then fell off sharply at higher temperatures. Rodger and others (1984) reported peak activity at $60{ }^{\circ} \mathrm{C}$ in the squid Loligo forbesi at $\mathrm{pH}$ 240 7.5. Working with the same species as in our study (Todaropsis eblanae), Ayensa and others (1999) observed two peaks in enzymatic activity at $\mathrm{pH} 7$, at 40 and $65{ }^{\circ} \mathrm{C}$, though they recorded much higher values than the values found here. These differences could be attributable to an eventual greater accumulation of degradation peptides in the squid used in the present work, greatly reducing proteolytic 
activity and also yielding high values for the blank readings. In contrast, Hurtado and others (2002) found values for octopus (Octopus vulgaris) muscle at $\mathrm{pH} 6.5$ that were much closer to the values reported here and also observed two peaks in activity, one at $40{ }^{\circ} \mathrm{C}$ and the other at $60{ }^{\circ} \mathrm{C}$. As we report here for Todaropsis eblanae, they also reported that pressurization failed to alter the temperature profile 248 of proteolytic activity.

\section{Profile of myofibrillar proteins}

252 Figure 2 presents the electrophoretic pattern of the soluble protein fraction from non-pressurized and high pressure-treated squid muscle after being held at $7^{\circ} \mathrm{C}$ and incubated at $40^{\circ} \mathrm{C}$ and $55^{\circ} \mathrm{C}$. In descending order of molecular weight, myosin heavy chain (MHC), paramyosin (PM), and actin (Ac) were recorded in all cases. Weaker bands were also observable between 45 and 15 KDa, largely

256 representing different kinds of troponins, tropomyosin and myosin light chain, along with bands for unidentified proteins which probably come from the sarcoplasmic fraction (Kariya and others 1986; Hurtado and others 1999). The band located between 220 and 97 KDa that is ordinarily associated with protein $\mathrm{C}$ may also correspond to fragments produced by the breakdown of MHC, as has been observed 260 by different researchers during the degradation of cephalopod mantle (Rodger and others 1984; Konno and Fukazawa 1993; Hurtado and others 2002). 


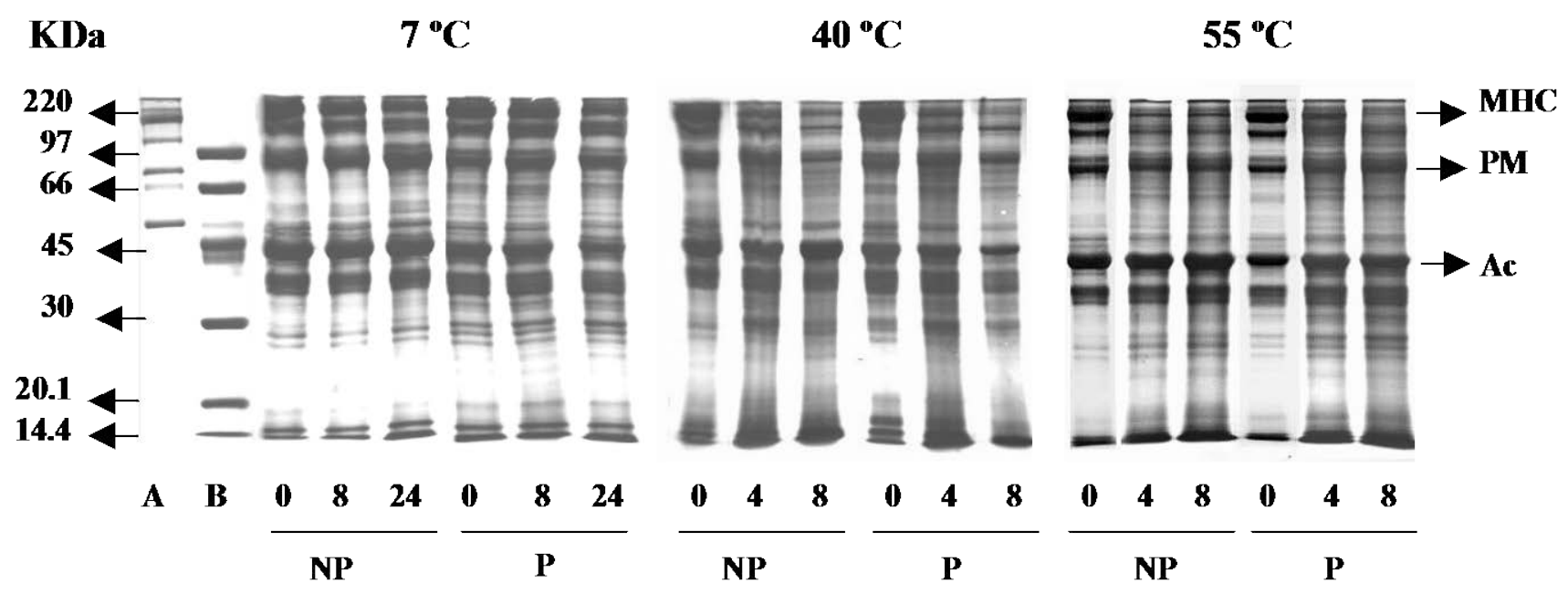

264 Figure 2. SDS-PAGE pattern for non-pressurized (NP) and pressurized (P) squid mantle muscle held at $7{ }^{\circ} \mathrm{C}$ and incubated at $40{ }^{\circ} \mathrm{C}$ and $55^{\circ} \mathrm{C}$ for various time periods, i.e., $0,8,24 \mathrm{~h}$ and 0,4 , and $8 \mathrm{~h}$, depending on temperature. A: high molecular weight standard; B: low molecular weight standard; MHC: myosin heavy chain; PM: paramyosin; Ac: actin.

Observing the electrophoretic profiles for non-pressurized (NP) and pressurized (P) muscle stored at chilled temperature for 0,8 , and $24 \mathrm{~h}$, the difference in the profiles for the two types of muscle at time 0 stands out. The number of bands increased on pressurized batch, indicative of hydrolysis with the 272 formation of lower molecular weight peptides upon high-pressure treatment. The myosin heavy chain (MHC) in batch NP had undergone slight proteolysis after $24 \mathrm{~h}$, but this was not yet perceptible at $8 \mathrm{~h}$. MHC breakdown was higher in batch P. Additionally, the actin band in batch P was altered slightly after incubation for 24 h. Fernández-Martín and others (1998) pointed out that pressurization at non276 denaturing temperatures resulted in unfolding of the actin in blue whiting (Micromesistius poutassou) muscle, the degree of unfolding increasing with pressure. In this sense, it may be that unfolding makes the actin more susceptible to degradation by the proteases.

At $40{ }^{\circ} \mathrm{C}$ the $\mathrm{MHC}$ band exhibited substantial degradation, to the point where this band was practically no longer visible after incubation for 8 h, especially in batch P. The higher degree of MHC breakdown in the pressurized muscle might be associated with the rise in proteolytic activity recorded at $40{ }^{\circ} \mathrm{C}$ (Fig. 
1). As in the case of the muscle held at $7^{\circ} \mathrm{C}$, actin band intensity decreased in batch $\mathrm{P}$ after incubation for $8 \mathrm{~h}$.

284 The electrophoretic profiles for batch NP at $55{ }^{\circ} \mathrm{C}$ were the same after incubation for 4 and 8 h, may be due to thermal inactivation of the relevant enzymes. Actin was not affected in either of the batches at this temperature, probably due to its higher thermostability. The myosin heavy chain in batch $\mathrm{P}$ underwent heavy proteolysis, quite considerable after incubation for $4 \mathrm{~h}$ and complete after $8 \mathrm{~h}$. This was consistent with the higher proteolytic activity observed following pressurization at $55^{\circ} \mathrm{C}$ (Fig. 1). The enzymes responsible are probably lysosomal cysteine proteases like cathepsin B and cathepsin L, previously described in squid (Todaropsis eblanae) mantle (Ayensa and others 1999), which are active at neutral $\mathrm{pH}$ and have proved to be more active at temperatures above $40{ }^{\circ} \mathrm{C}$. These enzymes are 292 probably released from the lysosomes as a result of the effect of high-pressure treatment. Homma and others (1994) reported increased cathepsin B, D, and L activity in pressurized bovine muscle extract. Alkaline proteases, which are capable of acting at neutral $\mathrm{pH}$ and are not activated at temperatures below $50{ }^{\circ} \mathrm{C}$, are another factor to be taken into account (Makinodan and others 1987). Nevertheless, Toyohara and others (1990) reported low levels of activity of heat-stable alkaline proteases on MHC in threadfin bream (Nemipterus bathybius) muscle at pH 7 and 8 at $65^{\circ} \mathrm{C}$. Cathepsin $\mathrm{D}$, lysosomal aspartic protease, is another enzyme that may be involved (Ayensa and others 1999), and even though acid pH conditions are the optimal conditions for activity by this enzyme, it may nonetheless act on the different 300 myofibrillar proteins at physiological muscle pH levels. Jiang and others (1992) suggested that cathepsin D played a role in post-mortem breakdown of fish muscle observed in the form of increased hydrolysis of the myofibrillar proteins in tilapia (Tilapia nilotica) incubated with cathepsin $\mathrm{D}$ at $\mathrm{pH} 6$ and 6.5 at low temperature.

304 Paramyosin, a characteristic protein in invertebrates, was unaltered in both batches under all the conditions tested in this study. This disagrees with the findings reported by Hurtado and others (2002), who observed unmistakable degradation of the paramyosin in non-pressurized octopus (Octopus 
vulgaris) muscle after incubation at $40{ }^{\circ} \mathrm{C}$, though not at $60{ }^{\circ} \mathrm{C}$. They also found that pressure treatment

\section{Effect of pH on proteolytic activity}

Figure 3A depicts the profile of proteolytic activity in batch NP at different pH levels at 40 and $55^{\circ} \mathrm{C}$. At $40{ }^{\circ} \mathrm{C}$ values were low, exhibiting a slight tendency to increase under acid $\mathrm{pH}$ conditions. In comparison, proteolytic activity displayed a significant increase at $\mathrm{pH} 3$ and $55^{\circ} \mathrm{C}$, with another, minor peak in activity at $\mathrm{pH} 5$.

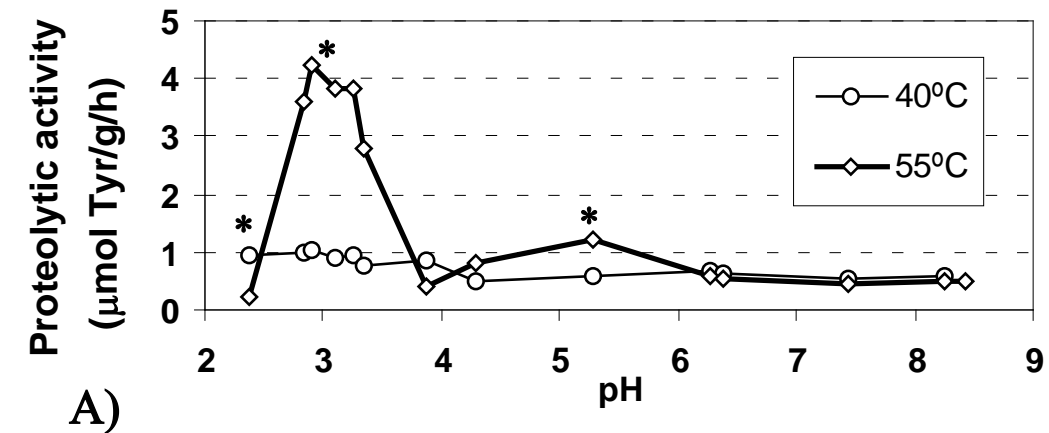

\begin{tabular}{ccccccc}
\hline & \multicolumn{7}{c}{$\mathbf{p H}$} \\
Temperature $\left({ }^{\circ} \mathrm{C}\right)$ & 2.5 & $3-3.5$ & $4-4.5$ & 5 & $6-7.5$ & $8-8.5$ \\
40 & a b & a & ab & b & b & b \\
55 & a & b & ac & d & c & c \\
\hline
\end{tabular}

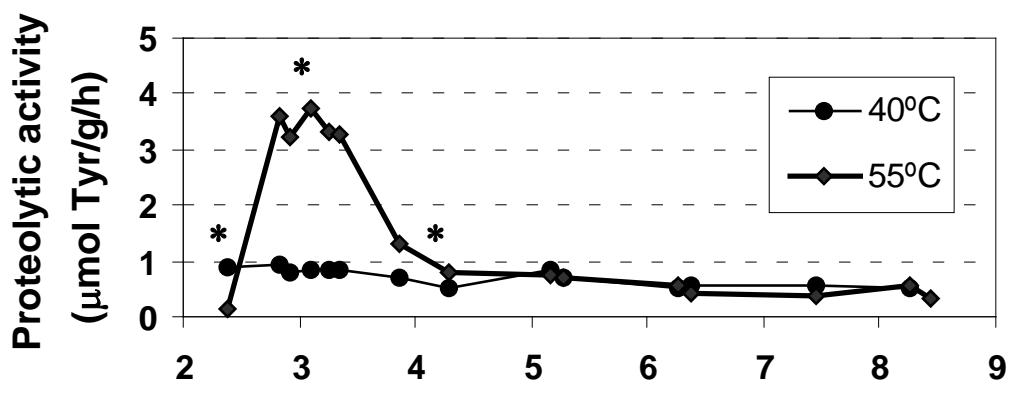
B) pH

\begin{tabular}{ccccccc}
\hline & \multicolumn{7}{c}{$\mathbf{p H}$} \\
Temperature $\left({ }^{\circ} \mathrm{C}\right)$ & 2.5 & $3-3.5$ & $4-4.5$ & 5 & $\mathbf{6 - 7 . 5}$ & $\mathbf{8 - 8 . 5}$ \\
40 & ab & b & a & ab & a & ab \\
55 & a & b & c & c & a & a \\
\hline
\end{tabular}


Figure 3. Proteolytic activity profile for non-pressurized (A) and pressurized (B) squid mantle muscle at different $\mathrm{pH}$ levels. Different letters $(\mathrm{a}, \mathrm{b}, \mathrm{c})$ indicate significant differences $(\mathrm{p} \leq 0.05)$ between $\mathrm{pH}$ values at each temperature. $(*)$ indicates significant differences $(\mathrm{p} \leq 0.05)$ between the two temperatures 320 at each $\mathrm{pH}$.

For the high pressure-treated batch (P) (Fig. 3B) at $40{ }^{\circ} \mathrm{C}$, proteolytic activity was unchanged at all the $\mathrm{pH}$ levels tested. In contrast to the results at $40{ }^{\circ} \mathrm{C}$, as in batch NP at $55^{\circ} \mathrm{C}$ there was a significant peak 324 in activity over the $\mathrm{pH}$ range of 2 to 4.5, with $\mathrm{pH} 3$ being optimal for proteolytic activity.

Other researchers have also recorded high proteolytic activity in cephalopods at acid pH levels. Sakai and others (1981) found that activity in Ommastrephes sloani pacificus peaked at pH 2.9 at $35^{\circ} \mathrm{C}$. Leblanc and Gill (1982) observed two peaks in activity, one at pH 2.6 in Illex illecebrosus and another at pH 3.6 in Loligo pealei.

Hurtado and others (2002) reported two sets of optimal conditions for activity in non-pressurized octopus (Octopus vulgaris) muscle at acid pH levels, one at $\mathrm{pH} 2.5$ at $40{ }^{\circ} \mathrm{C}$ and another higher peak at $\mathrm{pH} 4$ at $60^{\circ} \mathrm{C}$. In pressure-treated muscle they found that proteolytic activity decreased at the first peak but increased at the second peak. These findings are consistent with the observations made in our experiment (Fig. 3), in that proteolytic activity decreased slightly at $\mathrm{pH} 3$ at $40{ }^{\circ} \mathrm{C}$ and $\mathrm{pH} 4$ at $55^{\circ} \mathrm{C}$ but 336 increased significantly at pH 5 and $55^{\circ} \mathrm{C}(\mathrm{p} \leq 0.05)$.

\section{Effect of enzyme inhibitors and activators on proteolytic activity}

340 The effect of specific enzyme inhibitors on proteolytic activity was study at the optimum pH level at the two critical temperatures of $40{ }^{\circ} \mathrm{C}$ (Fig 4A) and $55^{\circ} \mathrm{C}$ (Fig. 4B), conditions at which peak activity had previously been observed (Fig. 1). 
A)

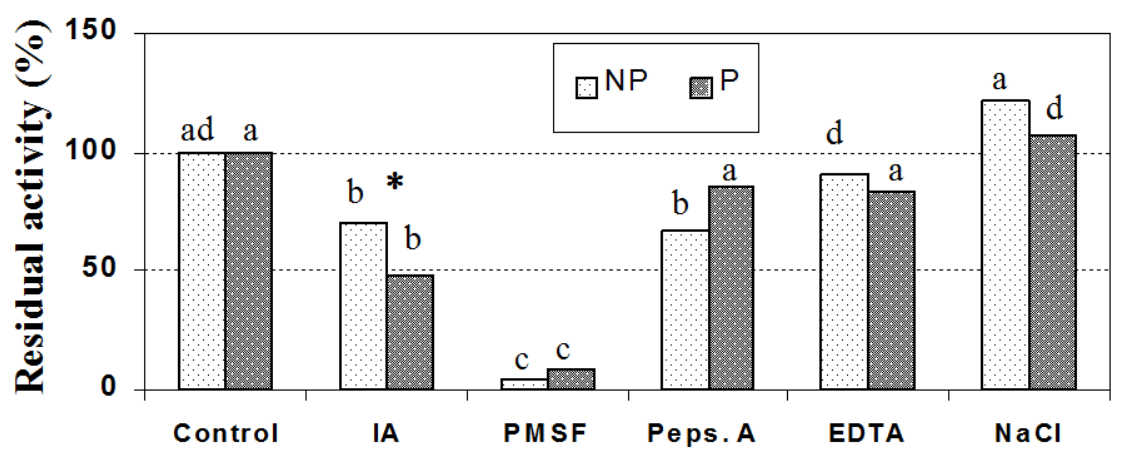

B)

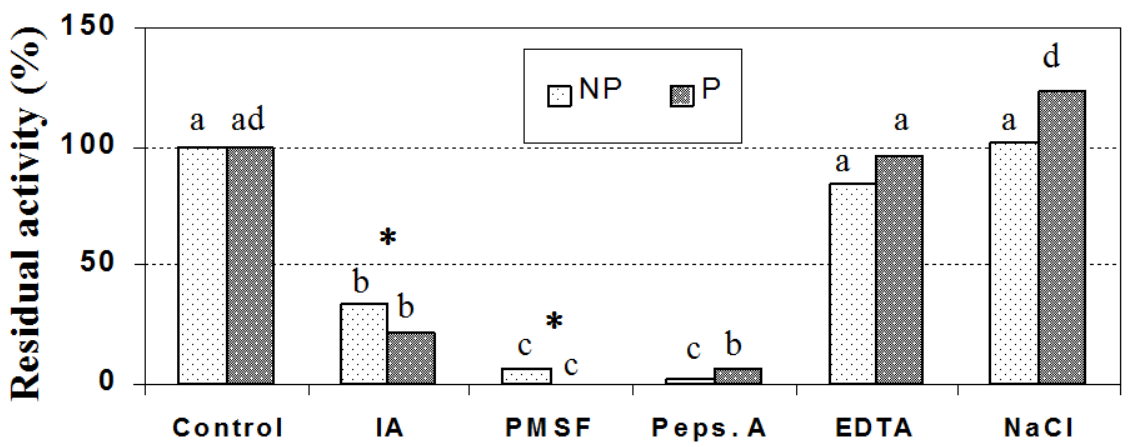

344 Figure 4. Effect of protease inhibitors and $\mathrm{NaCl}$ on proteolytic activity levels in non-pressurized (NP) and pressurized (P) squid mantle muscle incubated at $\mathrm{pH} 3$ at $40^{\circ} \mathrm{C}(\mathrm{A})$ and at $55^{\circ} \mathrm{C}$ (B). Different letters (a, b, c, d) indicate significant differences $(\mathrm{p} \leq 0.05)$ between the inhibitors in each batch. $\left(^{*}\right)$ indicates significant differences ( $\mathrm{p} \leq 0.05$ ) between the batches, NP and $\mathrm{P}$, for each inhibitor.

The figure plots percentage residual activity following application of specific inhibitors and $\mathrm{NaCl}$ compared with a control with no additives representing $100 \%$ activity. PMSF, which mainly inhibits serine proteases, produced the greatest decrease in activity levels (> $95 \%$ ) in both batches. Significant reductions were also observed for the cysteine and aspartic proteases, with about $70 \%$ residual activity recorded in both cases. Accordingly, the acid serine proteases active at $40{ }^{\circ} \mathrm{C}$ were unaffected by the high-pressure treatment, unlike the acid cysteine proteases, which exhibited around $20 \%$ more inhibition in batch $\mathrm{P}$ than in batch NP. This suggests that pressurization either led to an increase in acid cysteine proteases by rupturing the lysosomes or resulted in greater accessibility of the substrate. 
Pepstatin A brought a slight significant reduction in aspartic protease activity, but not after pressure treatment at this $\mathrm{pH}$ and temperature. EDTA and $\mathrm{NaCl}$ did not significantly alter enzymatic activity. Hurtado and others (2002) found that a concentration of $20 \mathrm{mM} \mathrm{NaCl}$ brought about an increase in proteolytic activity in octopus (Octopus vulgaris) muscle at $\mathrm{pH} 2.5$ at $40{ }^{\circ} \mathrm{C}$ and that pressure treatment inhibited the enzymes responsible for the increase. They also found that adding $\mathrm{NaCl}$ increased activity levels in pressurized octopus muscle at $\mathrm{pH} 4$ at $60^{\circ} \mathrm{C}$.

Figure $4 \mathrm{~B}$ depicts the effects at $\mathrm{pH} 3$ and at $55^{\circ} \mathrm{C}$, the conditions at which peak activity had 364 previously been observed. At this $\mathrm{pH}$ and temperature the inhibitory effect of PMSF was very high in both batches, as it was at $40{ }^{\circ} \mathrm{C}$. However, acid serine protease activity in the pressure-treated batch was higher than in the control batch, suggesting the release of these enzymes from the lysosomes or greater accessibility of the substrate due to structural changes brought about by pressurization. Inhibition of aspartic proteases by pepstatin A was nearly $95 \%$ in both batches, hence it follows that high pressure did not affect the activity of these enzymes at $\mathrm{pH} 3$ at either of the temperatures considered, though $55{ }^{\circ} \mathrm{C}$ is optimum for this enzymatic activity. Pepstatin A is known to be a good inhibitor of cathepsin D. Hence, the maximum proteolytic activity recorded at $\mathrm{pH} 3$ and $55^{\circ} \mathrm{C}$ might be ascribable to the presence 372 of cathepsin D. In this sense Gildberg (1987) characterized a cathepsin D from the digestive gland of squid (Todarodes sagittatus) with an optimum temperature found at $55^{\circ} \mathrm{C}$.

Inhibition of acid cysteine proteases by iodoacetic acid was higher at $55^{\circ} \mathrm{C}$ than at $40{ }^{\circ} \mathrm{C}$, nearly $60 \%$ in batch NP and significantly greater in batch P. Thus, the response of these enzymes to pressurization at $376 \mathrm{pH} 3$ was similar at both temperatures tested, though enzymatic activity was higher at $55^{\circ} \mathrm{C}$. Because of the acid $\mathrm{pH}$ used in the study, in all likelihood these enzymes were principally cathepsins. Ayensa and others (1999) reported that certain cysteine proteases were present in squid (Todaropsis eblanae) mantle, specifically confirming the presence of cathepsins B and L, which they observed to be more 380 active at temperatures higher than $40^{\circ} \mathrm{C}$. The inhibitory effect produced by pepstatin A showed cathepsin $\mathrm{D}$ to be present in the squid mantle muscle, and the peak in proteolytic activity at $\mathrm{pH} 3$ at $55^{\circ} \mathrm{C}$ was probably attributable to this protease. The high inhibitory effect of PMSF was indicative of 
the presence of serine proteases, but since PMSF also partially inhibits cysteine proteases, it will also be

responsible for a certain proportion of the inhibition of cysteine protease activity.

In addition to studying enzyme activity at the optimum $\mathrm{pH}$ level, enzyme activity was also characterized at physiological $\mathrm{pH}$ and at a basic $\mathrm{pH}$, both at $40{ }^{\circ} \mathrm{C}$, in order to establish whether neutral and alkaline proteases were present in addition to the acid proteases. At $\mathrm{pH} 6.5$ and $40{ }^{\circ} \mathrm{C}$ (data not shown) the proteolytic activity was quite low, with very little difference in activity between the blank and the control in both, the non-pressurized and pressurized muscle. For batch NP, moreover, there were no significant differences ( $\mathrm{p} \leq 0.05$ ) between the control and the samples for any of the inhibitors tested. Pressurization, by the same token, likewise did not seem to exert any influence on the neutral proteases in the squid muscle. In contrast, working with the same species used in this study (Todaropsis eblanae), Ayensa and others (1999) observed appreciable inhibition by $\mathrm{PMSF}$ and pepstatin $\mathrm{A}$ at $\mathrm{pH} 7$ at $40{ }^{\circ} \mathrm{C}$, which they attributed to the neutral serine and aspartic proteases active at that $\mathrm{pH}$. These dissimilar results might be related to dissimilarities in initial muscle quality.

396 At $\mathrm{pH} 8$ and $40{ }^{\circ} \mathrm{C}$ (data not shown), there was, first of all, a significant difference (p $\left.\leq 0.05\right)$ in the concentrations of soluble oligopeptides between the blanks for the untreated and pressure-treated muscle. This difference may have been caused by protein hydrolysis taking place on pressurization, and a similar difference was also observed in the electrophoretic analysis results (Fig. 2). In the non400 pressurized muscle adding inhibitors and $\mathrm{NaCl}$ did not give rise to any significant differences in proteolytic activity between the control and the samples, indicative of little alkaline protease activity in the conditions of the experiment. By comparison, addition of PMSF or EDTA to the pressure-treated muscle resulted in a significant decrease in proteolytic activity with respect to the control, respectively 404 indicative of increased activity by the alkaline serine proteases and alkaline metallo-proteases. Ayensa and others (1999) reported the presence of alkaline cysteine proteases in squid (Todaropsis eblanae) muscle at $\mathrm{pH} 9$ at $40{ }^{\circ} \mathrm{C}$ and $65^{\circ} \mathrm{C}$. Further study at higher $\mathrm{pH}$ levels and temperatures would be interesting with a view to confirming the presence of alkaline proteases and to profiling how their 408 activity might be altered by high-pressure treatment. 


\section{Influence of $\mathrm{NaCl}$ on proteolytic activity in squid muscle}

Earlier in this study a concentration of $20 \mathrm{mM} \mathrm{NaCl}$ was observed to have no effect on proteolytic

412 activity in the squid muscle in any of the conditions tested. Even so, since $\mathrm{NaCl}$ is an ingredient widely used in processing cephalopods, alterations in proteolytic activity at a concentration of $0.15 \mathrm{M} \mathrm{NaCl}$ were also studied. This concentration was chosen because it is commonly employed in making gels from muscle. Figure 5 depicts the results for proteolytic activity in squid muscle homogenized with $0.15 \mathrm{M}$ $416 \mathrm{NaCl}$ and then incubated at 40 and $60^{\circ} \mathrm{C}$ for $1 \mathrm{~h}$ compared with muscle homogenized in phosphate buffer at $\mathrm{pH} 6.5$.

$\mathrm{NaCl}$ inhibited proteolytic activity at $40{ }^{\circ} \mathrm{C}$ (Fig. 5A) was greater in the non-pressurized muscle, 420 attaining nearly $70 \%$ inhibition. The overall decrease in proteolytic activity at high concentrations of $\mathrm{NaCl}$ is most likely due to the inhibition of certain alkaline proteases (principally cysteine and serine proteases) that are active at neutral pH levels. Toyohara and others (1990) previously showed that heatstable alkaline proteases that were inactivated by $\mathrm{NaCl}$ were present in threadfin bream (Nemipterus 424 bathybius).

A)

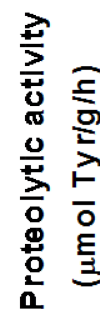

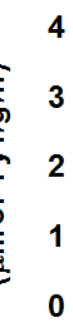

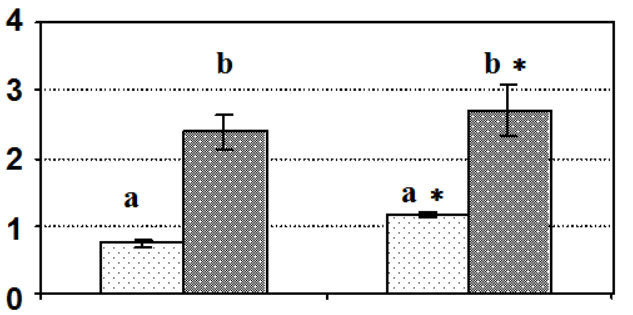

NP

$\mathbf{P}$
B)

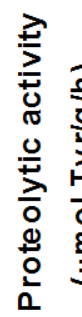

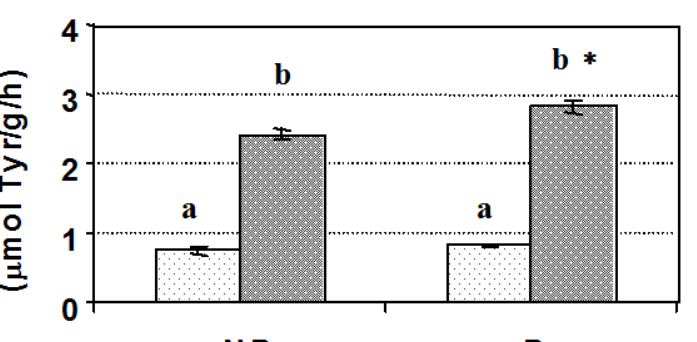

N P

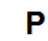

$0.15 \mathrm{M} \mathrm{NaCl}$

Control

Figure 5. Effect of $0.15 \mathrm{M} \mathrm{NaCl}$ on proteolytic activity in non-pressurized (NP) and pressurized (P) squid mantle muscle incubated at $40^{\circ} \mathrm{C}$ (A) and $60^{\circ} \mathrm{C}(\mathrm{B})$. Different letters (a, b) indicate significant differences ( $\mathrm{p} \leq 0.05$ ) between the NaCl-containing and control batches for each treatment (NP and P). 
$\left.{ }^{*}\right)$ indicates significant differences $(\mathrm{p} \leq 0.05)$ between the NP and P batches at each condition $(\mathrm{NaCl}-$ containing or control).

432 Proteolytic activity increased significantly with pressure for both the muscle homogenized with $\mathrm{NaCl}$ and the muscle homogenized in pH 6.5 phosphate buffer (control), with a higher increase in the presence of $\mathrm{NaCl}$. This could be ascribed to the presence of cathepsin $\mathrm{C}$, a chloride ion dependent lysosomal cysteine protease presumably released by high-pressure treatment. The chloride ion has been reported to

436 be required for proteolytic activity through activation of cathepsin C present in short-finned squid (Illex illecebrosus) muscle (Hameed and Haard 1985). Konno and Fukazawa (1993) also observed an increase in proteolytic activity in squid (Todarodes pacificus) mantle at higher concentrations of $\mathrm{NaCl}$, with peak activity taking place at a concentration of $0.3 \mathrm{M}$ at pH 7 at $40{ }^{\circ} \mathrm{C}$. They related the increased proteolytic 440 activity to NaCl-induced unfolding of the myosin, which then became more susceptible to the action of the proteases. Kinoshita and others (1990) characterized two serine proteases in crucian carp (Carassius auratus cuvieri) muscle that were only active at high temperatures $\left(50^{\circ} \mathrm{C}\right.$ and $60{ }^{\circ} \mathrm{C}$ ) and an $\mathrm{NaCl}$ concentration of at least $1 \%$.

$444 \mathrm{NaCl}$ inhibited proteolysis by about $70 \%$ in both the pressure-treated and untreated muscle at $60{ }^{\circ} \mathrm{C}$ (Fig. 5B). On the other hand, proteolytic activity was not observed to increase in the presence of $\mathrm{NaCl}$ on pressurization. This difference with respect to incubation at $40^{\circ} \mathrm{C}$ (Fig. 5A) is probably the result of inactivation of cathepsin $\mathrm{C}$ at the higher temperature. Carp cathepsin $\mathrm{C}$ has been reported to remain 448 stable at $60{ }^{\circ} \mathrm{C}$ for only 20 min (Makinodan and Ikeda 1971).

In conclusion, pressurization did not bring about any appreciable alteration in proteolytic activity, possibly because of the low initial proteolytic activity levels in the raw material. In consequence, 452 changes in the gelling capacity of pressure-treated and untreated muscle should not be expected when manufacturing restructured products from this particular squid lot. Moreover the addition of salt at 
concentration used as ingredient in restructured product would favor the inhibition of proteolytic activity.

\section{References}

An H, Weerasinghe V, Seymour TA, Morrisey MT. 1994. Cathepsin degradation of Pacific whiting 460 surimi proteins. J Food Sci 59: 1013-1017, 1033.

Angsupanich K, Ledward DA. 1998. High pressure treatment effects on cod (Gadus morhua) muscle. Food Chem 63: 39-50.

A.O.A.C. 2000. Official method of analysis. $17^{\text {th }}$ ed. Association of Official Analytical Chemistry. 464 Maryland, USA.

Ayensa MG, An H, Gómez-Guillén MC, Montero P, Borderías AJ. 1999. Partial protease activity characterization of squid (Todaropsis eblanae) mantle. Food Sci Tech Int 5: 391-396.

Bligh EG, Dyer WJ. 1959. A rapid method of total lipid extraction and purification. Can J Biochem 468 Phys 37: 911-917.

Bradford MM. 1976. A rapid and sensitive method for quantitation of microgram quantities of protein utilizing the principle of protein-dye binding. Anal Biochem 72: 248-254.

Chung YC, Gebrehiwot A, Farkas DF, Morrisey MT. 1994. Gelation of surimi by high hydrostatic 472 pressure. J. Food Sci 59: 523-524.

Defaye AB, Ledward DA. 1995. Pressure-induced dimerisation of metamyoglobin. J. Food Sci 60: 262-265. 
Dufour E, Dalgalarrondo M, Hervé G, Goutefongea R, Haertlé T. 1996. Proteolysis of type III collagen 476 by collagenase and cathepsin B under high hydrostatic pressure. Meat Sci 42: 261-269.

Ebina H, Nagashima Y, Ishizaki S, Takeshi T. 1995. Myosin heavy chain-degrading proteinase from spear squid muscle. Food Res Int 28: 31-36.

Fernández-Martín F, Pérez-Mateos M, Montero P. 1998. Effect of pressure/heat combinations on blue 480 whiting (Micromesistius poutassou) washed mince: thermal and mechanical properties. J Agric Food Chem 46: 3257-3264.

Gildber A. 1987. Purification and characterization of cathepsin D from the digestive gland of the pelagic squid Todarodes sagittatus. J Sci Food Agric 39: 85-94.

484 Gómez-Guillén MC, Hurtado JL, Montero P. 2002. Autolysis and protease inhibition effects on dynamic viscoelastic properties during thermal gelation of squid muscle. J Food Sci 67: 2491-2496.

Gómez-Guillén MC, Martínez-Álvarez O, Montero P. 2003. Functional and thermal gelation properties of squid mantle proteins affected by chilled and frozen storage. Food Sci 68: 1962-1967.

488 Gómez-Guillén MC, Solas MT, Borderías AJ, Montero P. 1996. Ultrastructure and rheological changes during the gelation of Giant squid (Dosidicus gigas) muscle. Z Lebensm Unters Forsch 202: 215-220.

Hameed KS, Haard FN. 1985. Isolation and characterization of cathepsin C from atlantic short finned squid (Illex illecebrosus). Comp Biochem Physiol 82B: 241-246.

492 Homma N, Ikeuchi Y, Suzuki A. 1994. Effects of high pressure treatment on the proteolytic enzymes in meat. Meat Sci 38: 219-228.

Hurtado JL, Borderias J, Montero P, An H. 1999. Characterization of proteolytic activity in octopus (Octopus vulgaris) arm muscle. J Food Biochem 23: 469-483. 
Hurtado JL, Montero P, Borderías J, Solas MT. 2001. High-pressure/temperature treatment effect on the characteristics of octopus (Octopus vulgaris) arm muscle. Eur Food Res Technol 213: 22-29.

Hurtado JL, Montero P, Borderías J, An H. 2002. Properties of proteolytic enzymes from muscle of octopus (Octopus vulgaris) and effects of high hydrostatic pressure. J Food Sci 67: 2555-2564.

500 Jiang SR, Wang YT, Chen CS. 1992. Lysosomal enzyme effects on the postmortem changes in tilapia (Tilapia nilotica X T. Aurea) muscle myofibrils. J Food Sci 57: 277-279, 282.

Kariya Y, Ochiai Y, Hashimoto K. 1986. Protein components and ultrastructure of the arm and mantle muscle of octopus (Octopus vulgaris). Bull Jap Soc Sci Fish 52: 131-138.

504 Kim K, Ikeuchi Y, Suzuki A.1992. Pressure-induced conversion of $\alpha$-connectin to $\beta$-connectin. Meat Sci 32: 237-243.

Kinoshita M, Toyohora H, Shimizu Y. Characterization of two distinct latent proteinases associated with myofibrils of crucian carp (Carassius auratus cuvieri). Comp Biochem Physiol 97B: 315-319.

508 Knudsen LB, Reimers K, Berner L, Jensen NC. 1985. A modification of Bligh and Dyer's oil method reducing chloroform vapour outlet. In: OEA/II 85 Western European Fish Technologists' Association (WEFTA). Hamburg, Germany.

Konno K, Fukazawa C. 1993. Autolysis of squid mantle muscle protein as affected by storage 512 conditions and inhibitors. J Food Sci 58: 1198-1202.

Laemmli UK. 1970. Cleavage of structural proteins during the assembly of head of bacteriophage T4. Nature 227: 860-865.

Leblanc EL, Gill TA. 1982. Comparative study of proteolysis in short-finned (Illex illecebrosus) and 516 long-finned (Loligo pealei Leseur) squid. Comp Biochem Physiol 73B: 201-210. 
Lowry OH, Rosebrough H, Farr AL, Randall RJ. 1951. Protein measurement with the Folin phenol reagent. J Biol Chem 193: 265-275.

Makinoda Y, Ikeda SA. 1971. Studies on fish muscle protease-V. The existence of cathepsin A, 520 cathepsin B and cathepsin C Bull Jap Soc Sci Fish 37: 1002-1006.

Makinoda Y, Yokoyama Y, Kinoshita M, Toyohara H. 1987. Characterization of an alkaline proteinase of fish muscle. Comp Biochem Physiol 87B: 1041-1046.

Montero P, Pérez-Mateos M, Solas T. 1997. Comparison of different gelation methods using sardine 524 (Sardina pilchardus) mince: effect of temperature and pressure. J Agric Food Chem 45: 4612-4618.

Morild E. 1981. The theory of pressure effects on enzyme. Adv Prot Chem 34: 93-166.

Nagashima Y, Ebina H, Nagai T, Tanaka M, Taguchi T. 1992. Proteolysis affects thermal gelation of squid mantle muscle. J Food Sci 57: 916-917,922.

528 Nagashima Y, Ebina H, Tanaka M, Taguchi T. 1993. Effect of high hydrostatic pressure on the thermal gelation of squid mantle meat. Food Res Int 26: 119-123.

Ohmori T, Shigehisa T, Taji S, Hayashi R. 1991. Effect of high hydrostatic pressure on the protease activities in meat. Agric Biol Chem 55: 357-361.

532 Pérez-Mateos M, Montero P. 1997. High-pressure-induced gel of sardine (Sardina pilchardus) washed mince as affected by pressure-time-temperature. J Food Sci 62: 1183-1188.

Rodger G, Weddle RB, Craig P, Hasting R. 1984. Effect of alkaline protease activity on some properties of comminuted squid. J Food Sci 49: 117-123.

536 Sakai J, Matsumoto JJ. 1981. Proteolytic enzymes of squid mantle muscle. Comp Biochem Physiol 68B: 389-395. 
Sakai J, Sakaguchi Y, Matsumoto J. 1981. Acid proteinase activity of squid mantle muscle: some properties and subcellular distribution. Comp Biochem Physiol 70: 791-794.

540 Seymour TA, Morrisey MT, Margo YP, An H. 1994. Purification and characterization of Pacific whiting proteases. J Agric Food Chem 42: 2421-2427.

Toyohara H, Kinoshita M, Shimizu Y. 1990. Proteolytic degradation of Threadfin-Bream meat gel. J Food Sci 55: 259-260.

544 Vyncke W. 1981. In: pH of fish muscle: comparison of methods. En Western European Fish Technologists’ Association (WEFTA). Copenhagen, Denmark.

Wasson DH. 1992. Fish muscle proteases and heat-induced myofibrillar degradation: a review. J Aquatic Food Prod Technol 1: 23-41.

\section{ACKNOWLEDGEMENT}

This research was supported by the Spanish Comisión Internacional de Ciencia y Tecnología mainly 552 under project ALI AGL2000-1497. The authors thank the Comunidad de Madrid (CAM) for Ms. Hernández’ predoctoral fellowship. 